\title{
Dolus Trump: Presidential Lies and the 2016 Masterclass on Truth-Bending
}

\begin{abstract}
Rückschau mit Fug und Recht als das Jahr bezeichnet werden, in dem insbesondere im anglophonen Raum neue Formen und Effekte postfaktischen Erzählens erstmals offen zutage traten. Ein Interview, in dem Colin Powell, ehemaliger Außenminister der Vereinigten Staaten, Fehler bei der Rechtfertigung des Kriegs gegen den Irak mit Hilfe falscher Tatsachenbehauptungen (Existenz von Massenvernichtungswaffen) einräumte, markiert das Ende einer Ära, in der die Lüge im politischen Diskurs noch nicht zum guten Ton gehörte. Das änderte sich mit der Wahl von Donald Trump zum Präsidenten der Vereinigten Staaten; wie Dolus, die Personifikation der Täuschung in der antiken Mythologie, wurde er zum Inbegriff einer politischen (Un-)Kultur, die aus strategischen Gründen systematisch die Grenzen zwischen Wahrheit und Lüge überschreitet. Am Beispiel des gescheiterten Amtsenthebungsverfahrens zeigt der Beitrag, dass das traditionelle System der „checks and balances“ heute an seine Grenzen stößt.
\end{abstract}

\section{Introduction}

In ancient Greek myth, truth starts with a story. Thanks to Aesop, the poet whose fables capture the spirit of a worldview grounded in personified virtues and a bewildering array of Titans, gods, and helpers, the narrative origins of truth and deception are readily available for the twenty-first century reader. Fable 530, titled "Prometheus and Truth," not only explains why lies have short legs, but also assures us that Truth (lat., Veritas) and Trickery (lat., Dolus) have always been two sides of the same coin. Both may be said to follow similar motivations: the attempt to influence people's decisions and worldviews. Thus, the noble intention to regulate people's behavior by giving them a model of truth is not a far cry from the desire to manipulate others through lies masking as truths. Here is the full narrative, translated by Laura Gibbs:

Prometheus, that potter who first gave shape to our new generation, decided one day to sculpt a statue of Truth, using all his skill so that she would be able to regulate people's behaviour. As he was working, an unexpected summons from mighty Jupiter called him

Roy Sommer, Bergische Universität Wuppertal, rsommer@uni-wuppertal.de

2 Open Access. (c) 2021 Roy Sommer, publiziert von De Gruyter. (c) BY Dieses Werk ist lizenziert unter der Creative Commons Attribution 4.0 International Lizenz.

https://doi.org/10.1515/9783110693065-004 
away. Prometheus left cunning Trickery in charge of his workshop (Trickery had recently become one of the god's apprentices). Fired by ambition, Trickery used the time at his disposal to fashion with his sly fingers a figure of the same size and appearance as Truth with identical features. When he had almost completed the piece, which was truly remarkable, he ran out of clay to use for her feet. The master returned, so Trickery quickly sat down in his seat, quaking with fear. Prometheus was amazed at the similarity of the two statues and wanted it to seem as if all the credit were due to his own skill. Therefore, he put both statues in the kiln and when they had been thoroughly baked, he infused them both with life: sacred Truth walked with measured steps, while her unfinished twin stood stuck in her tracks. That forgery, the product of subterfuge, thus acquired the name of Falsehood, and I readily agree with people who say that she has no feet: every once in a while something that is false can start off successfully, but with time Truth is sure to prevail. (Aesop 2008, 244)

The concluding sentence offers some solace in the face of the "assault on truth" (Kessler et al. 2020) which marks the presidency of "Number 45," as Paul Auster has chosen to call the current occupant of the White House: "A sign of disgust but also a small sign of hope that eventually there will be a Number 46." ${ }^{1}$ But how can we be so confident that truth will indeed prevail? Mythology can answer this, too. Veritas, the naked Goddess of Truth, may be less powerful than her capricious half-sister, the ancient Goddess of Fate; but both work hand in hand when it comes to politics and history. Fortune's "furious fickle wheel," as Pistol has it in Shakespeare's Henry $V$, issues a strong warning to unjust rulers. The wheel of fortune, symbol of change through the ages, has not lost its appeal: it serves as a symbol of hope for liberals and progressives worldwide who crave an end to the "age of confusion" and "shock politics" (Klein 2018) commonly associated with the Dolus of our time, "the most mendacious president in US history" (Kessler et al. 2020, x).

This essay explores the emergence and consequences of 'post-truth' public discourse in the United States, whose repercussions are felt across the globe. When the Oxford English Dictionary made the adjective 'word of the year,'2 a surge of populism on both sides of the Atlantic had already turned 2016 into a "nightmare" (Butler 2016) for liberals and progressives. With the help of Cambridge Analytica and illegally acquired Facebook profiles, Britain's 'Leave' campaign could win the 2016 EU referendum and Trump the general election.

1 Auster's comments are taken from an interview with I. B. Siegumfeldt and François Hugonnier published in the e-journal LISA: Literature, History of Ideas, Images and Societies of the English-Speaking World LISA: Literature, History of Ideas, Images and Societies of the EnglishSpeaking World (Siegumfeldt and Hugonnier 2020).

2 Cf. https://languages.oup.com/word-of-the-year/2016/ (July 17, 2020). 
Both relied heavily on fake news, science denial and a tribal politics which sought, and still seeks, to make meaningful communication impossible. More things happened that year: Colin Powell, former United States Secretary of State, gave an interview on the rationale behind the most consequential preTrump lie in twenty-first century American politics, George W. Bush's claim that Saddam Hussein was hiding weapons of mass destruction. Marco Rubio, a Republican senator who challenged Trump in the primaries, showed the world how easy it is to beat the bully at his own game if you are prepared to stoop really low. The tiny hands meme went viral, prompting Trump to defend the size of his manhood.

In retrospect, then, 2016 appears like an extended masterclass on truthbending. After exploring the lessons to be learnt from the populist experiment, the essay turns to a more recent chapter in post-truth discourse, the impeachment proceedings against Dolus Trump. Using a narrative approach, I will argue that two truth stories were in conflict: the inquiry's detective story and the trial's courtroom drama. In a partisan move, the Republican majority in the Senate refused to engage with the allegations against Trump, deciding to bypass truth completely: no witnesses were heard, no documents subpoenaed. This blunt dismissal of the point of the trial, of any trial, marks a low point in the decay of American political culture.

Restoring Truth after Trump will require more than a return to the status quo ante. If post-truth discourse is not the cause, but the symptom of such momentous global factors as post-democracy, a knowledge crisis, social injustice, and racial discrimination, as many commentators have argued, addressing these issues is unavoidable. From an epistemological perspective, however, the question remains how trust can be re-established in an aging political system whose flaws and fault lines Trump has not only exposed but shamelessly exploited. The essay ends with a plea for a new discourse on truth and truthfulness, inspired by the Truth and Reconciliation Commission which helped South Africa come to terms with apartheid.

\section{The 2016 Masterclass on Truth-Bending: Three Lessons}

Even though there may be only one truth after all (who knows?), there are different ways of telling and not telling it. Telling a true story well is not that easy, as narrative theorists and law experts have pointed out, examining the role of 
storytelling in court. In the adversarial system, where jurors process testimony, stories are "unavoidable" (Griffin 2013, 285) but by no means infallible. Confirmation bias, prejudice and juries influenced by perceived narrative authority rather than factual evidence have often been identified as flaws in the legal systems. ${ }^{3} \mathrm{~A}$ recent report confirms that such flaws still cause intolerable injustice: "African Americans are only 13\% of the American population but a majority of innocent defendants wrongfully convicted of crimes and later exonerated." "Several contextual factors determine the storytellers' perceived trustworthiness: the framing of their tales by media coverage of the case, racial prejudice, or generic expectations concerning the dramaturgy of a 'true' story. All these aspects may be more influential than the truth value of the narrative itself if you seek to put a name, or face, to guilt.

This is also true for the biggest pre-Trump truth-bending scandal in recent American politics. Like millions of cheaters, Bill Clinton lied to save his neck, and paid a price - an embarrassing impeachment trial. ${ }^{5}$ But the president whose falsehood changed the world by allowing Daesh, the self-acclaimed Islamic State, to rise from the ashes of a ruined Iraq, was never held to account. After 9/11, George W. Bush divided the world into the "axis of evil" (North Korea, Iran, and Iraq), a "coalition of the willing" ${ }^{\text {" }}$ which supported the US invasion of Iraq, and the remaining nations - these last being a clear majority.

One trustworthy account of the events preceding Bush's war against terror or against international law and human rights, depending on your point of view - comes from Colin Powell, United States Secretary of State from 2001 to 2005. In an interview with Jason M. Breslow published online in 2016, Powell discusses the events leading up to his 2003 speech to the United Nations Security Council in which he shared information on Iraq's alleged weapons of mass

3 Cf. Griffin (2013, 285): "Many social scientists who study juries have concluded that they interpret information not by considering and weighing each relevant piece of evidence in turn, but by constructing competing narratives and then deciding which story is more persuasive."

4 Cf. the National Registry of Exonerations compiled by the Newkirk Center for Science and Society at the University of California, Irvine: http://www.law.umich.edu/special/exoneration/Documents/Race_and_Wrongful_Convictions.pdf (July 17, 2020).

5 Monika Lewinsky, lest we forget, paid a disproportionately bigger price: online bullying, and public humiliation and shaming; cf. https://www.ted.com/talks/monica_lewinsky_the_price_ of_shame\#t-600509 (July 15, 2020).

6 The term is taken from the Wikipedia entry, cf. https://en.wikipedia.org/wiki/Coalition_of_the_willing (July 17, 2020). 
destruction (cf. Breslow 2016). ${ }^{7}$ In his retrospective, Powell makes no secret of the fact that war was a foregone conclusion. "Early in January," he recalls, "the president decided, 'Sorry, I cannot take the chance in this post-9/11 environment that somebody who might have or does have or is working on these weapons is allowed to continue in violation of U.N. resolutions.' And he made the decision in the middle of January that it was going to require military action" (qtd. in Breslow 2016, n.p.).

We now know that the evidence about non-existent 'biological vans' and chemical weapons which Powell presented, and which Bush had cited previously in speeches and in his State of the Union address, had been put together by the CIA on the basis of false information gathered from Iraqi defectors and exiles. It is important to add, however, that it is not the "bright light of hindsight," as the New York Times editors claimed in a statement in $2004,{ }^{8}$ which allows us to see that Bush's allegations were unfounded. Around the world, observers and commentators were under no illusions in 2003 that the evidence presented before the U.N. was neither conclusive nor plausible, but designed to justify the invasion of a sovereign state that was not implicated in the terrorist attack on the World Trade Center. Against this background, the mildly critical assessment by the New York Times of its own news coverage, which concludes that in some cases "information that was controversial then, and seems questionable now, was insufficiently qualified or allowed to stand unchallenged," must be dismissed as a lame excuse for a lack of journalistic rigor.

Tellability is the term which, in narrative theory, designates the appeal and newsworthiness of a story (cf. Baroni 2014). In the aftermath of 9/11, Bush had (wrongly) identified Saddam Hussein as one of the main culprits. Anything that implicated the Iraqi president in a plot against America was deemed inherently trustworthy. In Bush's State of the Union address in January 2003 the lack of conclusive evidence was compensated by an appeal to the imagination: "Imagine those 19 hijackers with other weapons and other plans - this time armed by Saddam Hussein. It would take one vial, one canister, one crate slipped into this country to bring a day of horror like none we have ever known.” (Bush 2003, n.p.) Imagination, not fact, creates the what-if scenario which yields a highly tellable story - another plot against America - and lends weight to Bush's re-

7 The full text of Powell's speech can be found here: https://www.theguardian.com/world/2003/feb/05/iraq.usa (July 17, 2020).

8 Cf. https://www.nytimes.com/2004/05/26/world/from-the-editors-the-times-and-iraq.html (July 17, 2020). 
solve: "We will do everything in our power to make sure that that day never comes." (Bush 2003, n.p.)

Literary theory calls this the willing suspension of disbelief. When reading fiction, we treat invented events as if they were real, and no harm is done. Suspense wouldn't work without this. In politics, the willing suspension of disbelief is a recipe for disaster, leading to what linguist and psychologist Stephen Pinker $(2007,7)$ has called "the most despised American foreign policy initiative since the war in Vietnam." In order to provide the missing link between Osama bin Laden, the Saudi Arabian mastermind behind 9/11, and Saddam Hussein's "evil" Iraq, the CIA provided Powell with another name and face: As Breslow (2016) notes, Abu Musab al-Zarqawi is mentioned 21 times in Powell's address to the Security Council. The American public, bent on retaliation, readily bought the story fed to them by the government and the nation's most respected investigative journalists who turned a blind eye to truth. Like the CIA, they should have been able to distinguish reliable sources from a couple of Iraqi dissidents with their own axe to grind.

But a state of exception is not the time for critical questions or rational discourse: a high degree of tellability plus an unhealthy dose of confirmation bias may suffice to transform a possibility, however unlikely, into a certainty. Anxiety, fear, hurt pride, and calls for retribution created a climate in which archaic truth stories in the style of the Old Testament - the battle between good and evil, an eye for an eye - readily gained currency among lawmakers. In 2002, Congress had passed a resolution with an overwhelming majority which authorized Bush to go to war. Colin Powell's prescient warning to his president, "If you break it, you own it," went unheard (qtd. in Breslow 2016, n.p.). Bush waged war in Iraq and Afghanistan without an exit strategy and allowed the CIA to torture and detain without trial so-called unlawful combatants, a newly introduced category. Not only did the end not justify the means; the means themselves stained America's reputation in the world. Bush's presidency will always remain tainted by images of Abu Ghraib.

Back to Colin Powell and the retrospective part of the 2016 masterclass on truth-bending. If there are any lessons to be learnt from history at all, it should be, first, that the end only justifies the means if you really know what you're doing. The Bush administration manifestly had no clue what they were up against. Future historians will have to decide how close Osama bin Laden came 
to his political goal of destabilizing the West's leading superpower. ${ }^{9}$ The caliphate may be off the table now, in 2020, but the self-inflicted long-term damage to America's reputation in the world following the invasion and occupation of Iraq far outweighs the short-lived sense of satisfaction which may have been felt in post-9/11 Washington.

The second lesson is more assuring. Bush's decisions may have been made in good faith, even though they violated international law. While he never apologized for his mistake, Bush stopped repeating his false claims once it became clear they were unfounded. In the pre-post-truth climate of the "war on terror," despite the serious backlash against foundational values and legal norms documented in a classified 2014 Senate report on torture, ${ }^{10}$ facts were still accepted as facts. Not finding any weapons of mass destruction meant they were nonexistent, and while there were no regrets, no one in their right mind would have claimed that alternative facts would render this conclusion irrelevant. Nor did Bush confuse his imaginative rhetoric with reality, or blame the "fake news" and the CIA for conspiring against him, or even fire Powell.

The third lesson to be learnt from the 2016 masterclass starts with the Cambridge Analytica scandal and the election of another Republican president, the "very stable genius." Trump makes us yearn for the predictability and reliability of Bush, let alone the far-sighted responsibility which characterized most of Obama's presidency. Not only the quantity, but also the quality of Trump's untrue claims is alarming: "He's not known for one big lie - just a constant stream of exaggerated, invented, boastful, purposely outrageous, spiteful, inconsistent, dubious and false claims" (Kessler et al. 2020, x). Is this a new political strategy designed to create confusion in the public sphere? David Leonhardt et al. were among the first to make that point: "Trump is trying to make truth irrelevant. It is extremely damaging to democracy, and it's not an accident. It's core to his political strategy.” (Leonhardt 2017, n.p.) A strategy grounded in narcissism, as psychologist Mary Trump (2020) confirms. For reasons we haven't yet fully understood, and with consequences which future presidents will find difficult to overcome, Dolus has been allowed to dabble with reality both in private and in public.

9 In 2006, Al-Jazeera published a full transcript of a videotaped speech by Osama bin Laden, authenticated by the CIA, cf. https://www.aljazeera.com/archive/2006/09/20084101264753 7920.html (July 17, 2020).

10 In December 2014, Barack Obama placed the Senate torture report in his presidential library, thus preserving it for future reference; however, the 6,700 page document, a result of more than six years of investigations led by Democrat Dianne Feinstein, will remain classified until 2027, and probably longer (cf. Ackermann 2016, n.p.). 
Leonhardt et al.'s tentative conclusions have turned out to be correct. Trump keeps lying, he ignores even the most undisputed facts about reality, mismanaging the Covid-19 pandemic, fostering racism in the wake of the George Floyd killing, hoping that white supremacists will keep him in office, and destroying what little cohesion is left in a divided nation. His days in office are numbered, give or take four years, but the lasting damage to the political system can only be ignored by those who fundamentally oppose that system or enjoy the chaos currently reigning in Washington D.C., a state of affairs whose repercussions are felt not only in the United States, but across the world.

In a "Letter on Justice and Open Debate," published online by Harper's Magazine on July 7, 2020, ${ }^{11}$ more than 150 writers, scholars and public intellectuals have expressed concern about the climate of intolerance which constricts the free exchange of information and ideas: "The forces of illiberalism are gaining strength throughout the world and have a powerful ally in Donald Trump, who represents a real threat to democracy." Perhaps predictably, three days later under the title "A More Specific Letter on Justice and Open Debate" a coalition against "cis white intellectuals" accused Harper's of giving a voice to those who already had ample opportunities to make their views heard, excluding minority people, and ignoring that the public sphere is a "diversifying industry." ${ }^{12}$ This response letter is indicative of the erosion of democratic principles pointed out by Margaret Atwood, J. K. Rowling, Martin Amis and Malcolm Gladwell, to name only four supporters of the original initiative: the dangerous illusion, brought about by social media, that everyone is always entitled to be heard, right here, right now.

Democracy is based not only on political representation (whether we like it or not, we can't all be presidents), but also on public representation: Much as we'd like it, we can't all raise our voices in the public sphere simultaneously. If everyone speaks, nobody will listen. And if nobody listens, nobody is getting heard, and there is no point in speaking out in the first place. Ignoring this foundational principle of discourse only serves to establish a new Babel: Communication will break down. And if statement A (Open letter) on issue B (censorship) is not a statement on issue $C$ (privilege), which you may find more pressing, this doesn't invalidate the claims made in statement A. A warning of the consequences of another Dolus government should not be turned into a controversy on privilege. Not because a debate on "who gets to have a platform"

11 Cf. https://harpers.org/a-letter-on-justice-and-open-debate/ (July 17, 2020).

12 Cf. https://theobjective.substack.com/p/a-more-specific-letter-on-justice (July 17, 2020); for additional information on the response letter, cf. Schuessler (2020, n.p.). 
or on "the elitism that still pervades the media industry" is not important. It is. But it is a different debate. Frustrating as it seems, we will have to go back to first principles to bring back Truth after Trump.

\section{A Truth Bypass: The Plot Twist in Trump's Impeachment}

Both Clinton's and Trump's impeachment trials have yielded a specific type of narrative which keeps news addicts hooked through suspense rather than surprise. It is not the ending that matters, but the way closure will be achieved. The reason is that, despite all claims to the contrary, the outcome was in both cases a foregone conclusion. Legal fictions of objectivity and bipartisan cooperation are quickly suspended if voting along party lines allows the defendant to stay in power. Thus, when Democrats decided to impeach Trump over allegations of an abuse of power and obstruction of Congress in 2019, commentators were quick to point out that a mirror-image replay of Bill Clinton's impeachment trial was the most likely scenario. In 1998, Clinton had been accused of lying under oath by a Republican congress, and acquitted by the Democratic majority in the Senate. Now, in February 2020, in a similar maneuver, the Republican Senate rejected the Democrats' allegations. Was history going to repeat itself?

The impeachment process consists of two phases, the inquiry in the House of Congress and the trial in the Senate. Both construct their own narrative, employing very different generic templates and ways of creating suspense. The inquiry, which I shall call truth story A, seeks to uncover secrets, to establish facts, and to present evidence in order to make a case against the president. Like a detective story, it is characterized by a duality, a presence of two stories: the story of the alleged crime and that of the investigation. ${ }^{13}$ Its findings were clear: Trump had abused his powers. The Senate trial, or truth story B, is reminiscent of a courtroom drama, albeit a pretty undramatic one, as Mitch McConnell, leader of the Republican majority in the Senate, made sure that the witness box remained empty. This is an extract from truth story A, "Articles of Impeachment Against Donald John Trump," ${ }^{14}$ from December 18, 2019:

13 I'm taking my cue here from Tzvetan Todorov's (2008 [1966]) typology of detective fiction.

14 Cf. https://www.congress.gov/116/bills/hres755/BILLS-116hres755enr.pdf (July 17, 2020). 
Using the powers of his high office, President Trump solicited the interference of a foreign government, Ukraine, in the 2020 United States Presidential election. He did so through a scheme or course of conduct that included soliciting the Government of Ukraine to publicly announce investigations that would benefit his reelection, harm the election prospects of a political opponent, and influence the 2020 United States Presidential election to his advantage. President Trump also sought to pressure the Government of Ukraine to take these steps by conditioning official United States Government acts of significant value to Ukraine on its public announcement of the investigations. President Trump engaged in this scheme or course of conduct for corrupt purposes in pursuit of personal political benefit. (Article I: Abuse of Power)

The narrative premise of truth story B may be traced back to a famous quote from Trump's personal lawyer, Rudy Giuliani: “Truth isn't truth," he said on August 19, 2018, in a televised interview with Chuck Todd, referring to contradictory claims made by Michael Flynn and Donald Trump. ${ }^{15}$ If this was true, and if facts are, today, in the eyes of the beholder, as Giuliani had claimed a week earlier, ${ }^{16}$ what is the point of a legal system with trials to establish who is right in a dispute? Once impeachment was underway, the White House defense team insisted that Trump had done "absolutely nothing wrong" and claimed that allegations were too "broad" to warrant impeachment. ${ }^{17}$ Too broad? The matter seemed pretty straightforward: a phone call, a threat, withholding aid. Abuse of power. More complex issues have been brought to court.

Trump publicly encouraged the Chinese and Ukranian governments to start investigations against Joe Biden and his son Hunter, creating the impression that this was normal behavior. Which, thanks to him, it has in a way now become. Robert Mueller concluded that the Russian government helped the Trump campaign in 2016. ${ }^{18}$ Why shouldn't enlisting foreign help work a second time?

15 Cf. https://www.youtube.com/watch?v=CljsZ7lgbtw (July 17, 2020).

16 Cf. https://eu.usatoday.com/story/news/politics/onpolitics/2018/08/15/rudy-giulianipresident-trump-honest-facts-eye-beholder/1002853002/ (July 17, 2020).

17 Cf. https://chicago.suntimes.com/2020/1/20/21074690/donald-trump-impeachment-trialmitch-mcconnell-democrats (July 17, 2020).

18 In an opinion piece for the Washington Post, former special counsel Robert Mueller (2020, n.p.) condemns Trump for commuting Roger Stone's sentence and makes it clear that Russian interference in the 2016 election really happened: “Russia's actions were a threat to America's democracy. It was critical that they be investigated and understood. By late 2016, the FBI had evidence that the Russians had signalled to a Trump campaign adviser that they could assist the campaign through the anonymous release of information damaging to the Democratic candidate. And the FBI knew that the Russians had done just that: Beginning in July 2016, WikiLeaks released emails stolen by Russian military intelligence officers from the Clinton 
Kessler et al. (2020, 260), in their survey of impeachment proceedings, point out that Trump also resorted to his tried-and-tested bully tactics: "Following the advice of his longtime lawyer and mentor, Roy Cohn, to always counter-attack, Trump constructed an alternative and false narrative - his phone call with the Ukranian president was 'perfect', not a possible abuse of power." Adopting the relativist strategies successfully employed by authoritarian rulers like Vladimir Putin, Trump "denied verified facts; his phone call to the Ukranian leader was not, as he insisted, 'perfect' but was so troublesome that numerous administration officials listening in immediately reported their concerns" (Kessler et al. 2020, 262).

The White House lawyers made sure that potential witnesses ignored subpoenas issued by Congress, and that incriminating evidence like the record of the phone call was kept from public scrutiny. Despite such precautions, the truth was hard to conceal. When asked about the quid pro quo during a press conference on October 19, 2019, Mick Mulvaney, White House chief of staff, made what may well have been the truest statement from the White House during the whole affair: "We do that all the time with foreign policy". He then continued: "I have news for everybody. Get over it. There is going to be political influence in foreign policy. That is going to happen." ${ }^{19}$ Finally he commented on the new direction in foreign policy: "Elections do have consequences, and they should, and your foreign policy is going to change. Obama did it in one way, and we're doing it in a different way, and there's no problem with that."

Who did Mulvaney have in mind when he said "we"? A collective we, referring to all administrations in general? Or the Trump administration in particular? And how exactly did the Trump administration differ, in his view, from the Obama administration when mixing politics and foreign policy? We will never know. Someone must have told Mulvaney to row back on his comments; later the same day, he insisted that there had been "absolutely no quid pro quo." On November 20, 2019, the United States Ambassador to the European Union, Gordon Sondland, contradicted that statement in public by confirming that "Mr. Giuliani's requests were a quid pro quo for arranging a White House visit for president Zelensky."20

campaign. Other online personas using false names - fronts for Russian military intelligence also released Clinton campaign emails.”

19 Cf. https://www.youtube.com/watch?v=lI4EbTic-lo (July 17, 2020).

20 During the inquiry Gordon Sondland, United States Ambassador to the European Union, confirmed that this is what he had been expected to arrange (cf. https://www.theguardian.com/us-news/video/2019/nov/20/trump-impeachment-there-was-a-quid-pro-quo-inukraine-scandal-says-key-witness-video [July 17, 2020]). 
When Senate majority leader Mitch McConnell announced during an interview on Fox News that he would be in "total coordination with the White House counsel” as the impeachment into President Donald Trump pressed forward, ${ }^{21}$ Democrats expressed concern that the trial would not be fair and impartial. In January 2020, McConnell, whom one commentator called a "vote-counting virtuoso,"22 announced that he had secured a majority of 51 votes. He had also managed to persuade Trump that a short trial was in his best interests. This time round, there were to be no sophisticated linguistic debates on the true meaning of words like is, as in Clinton's impeachment trial, ${ }^{23}$ although Mulvaney's "we" or "no" might have been strong candidates.

As the outcome was predictable by the time proceedings started, narrative interest changed: "what suspense," as narrative theorist Marie-Laure Ryan (2015 [2001], Ch. 4) calls the type of suspense that involves audiences in the unfolding of events, was replaced by "how suspense." What would happen was clear; but how would Republicans argue to dismiss the case? In February 2020, the Republican majority in the Senate duly turned down the Democratic request to subpoena documents and witnesses like former national security advisor John Bolton. "[T]his can't be the first impeachment trial in American history where there are no witnesses called and no document subpoenaed," Jason Crow, a Democrat, told reporters (qtd. in Luning 2020, n.p.). "I do not believe we need to hear from an 18th witness," Republican Senator Cory Gardner said (qtd. in Luning 2020). "A trial without witnesses and evidence is not a trial at all," tweeted John Hickenlooper who will challenge Gardner in the primaries (qtd. in Luning 2020, n.p.). Thus, courtroom drama turned into courtroom farce.

The Republicans had a majority but few options. In the face of the evidence presented by Nancy Pelosi, denial must have seemed too risky even to Trump devotees. What is more, the prospect of hearing John Bolton and others testify

21 Cf. https://eu.usatoday.com/story/news/politics/2019/12/12/mcconnell-total-coordinati-onwhite-house-impeachment-trial/4416518002/ (July 17, 2020).

22 Cf. https://edition.cnn.com/2020/01/31/politics/mitch-mcconnell-donald-trump-senateimpeachment-trial/index.html (July 17, 2020).

23 Cf. the Wikipedia entry on Clinton's impeachment on this amusing episode: "A muchquoted statement from Clinton's grand jury testimony showed him questioning the precise use of the word 'is'. Contending his statement that 'there's nothing going on between us' had been truthful because he had no ongoing relationship with Lewinsky at the time he was questioned, Clinton said, 'It depends upon what the meaning of the word 'is' is. If the - if he - if 'is' means is and never has been, that is not - that is one thing. If it means there is none, that was a completely true statement.”' (https://en.wikipedia.org/wiki/Impeachment_of_Bill_Clinton [July 17, 2020]) 
in public was a risk to be avoided at all costs; it would only have added to the embarrassment. But what is a trial that is not a trial? In order to secure authority and control over the impeachment narrative, McConnell stripped the kind of retrospective truth story we expect from courtroom drama (What happened when, and where? Who did what to whom, and why?) of all the qualities that render a discourse a narrative (events, characters, sequentiality, temporality, causality, agency). What do you do if you can't reject a claim as false? You declare it irrelevant.

“Tiny hands” Republican Senator Marco Rubio, who now fully supports Trump, explains this position in a short document titled "My Statements on the President's Impeachment Trial." ${ }^{24}$ First, Rubio seeks to bestow some historical dignity on the courtroom farce. When including impeachment in the Constitution, he speculates, the Framers - delegates to the 1787 Constitutional Convention - fully understood "how disruptive and traumatic it might be." They might, one should add, also have deemed it a strategy for bringing about national unity and healing after a severe political crisis. Rubio then rejects impeachment, pointing to the forthcoming elections:

I disagree with the House Managers' argument that, if we find the allegations they have made are true, failing to remove the President leaves us with no remedy to constrain this or future Presidents. Congress and the courts have multiple ways by which to constrain the power of the executive. And ultimately, voters themselves can hold the President accountable in an election, including the one just nine months from now.

This is quite amazing, given that Trump came to power with the help of dubious digital campaigning and the help of Russian interference, and that a renewed attempt at election-meddling is what constitutes the alleged abuse of power. Equally puzzling is Rubio's explanation of his approach to the question of truth.

I also reject the argument that unless we call new witnesses this is not a fair trial. They cannot argue that fairness demands we seek witnesses they did little to pursue. Nevertheless, new witnesses that would testify to the truth of the allegations are not needed for my threshold analysis, which already assumed that all the allegations made are true.

This statement turns courtroom drama into a thought experiment: What if everything the Democrats said was true? Rubio concludes this wouldn't matter, because higher values are at stake: "I will not vote to remove the President because doing so would inflict extraordinary and potentially irreparable damage

24 Cf. https://medium.com/@SenatorMarcoRubio/my-statement-on-the-presidents-impeachment-trial-9669e82ccb43 (July 17, 2020). 
to our already divided nation.” Regardless of whether this makes any sense, or whether it is at all true that Trump's removal would do more damage than another year in office, this is a cheap rhetorical maneuver: by "assuming" that the allegations are true, Rubio avoids saying whether he himself actually believes they are true or not; at the same time, this evasive strategy seemingly absolves him from the necessity to evaluate the claims thoroughly. Seen this way, witnesses and documents are indeed superfluous.

The task of a juror, and the point of a trial, however, is to establish the truth, first and foremost, and no thought experiment can be a substitute for looking at the evidence. Unless, like Giuliani, you claim that facts can't be established and everybody is entitled to their own, idiosyncratic version of the truth. If the truth is not contested, it need not be established. Rubio's statement is an eloquent, but rather obvious attempt to bypass the vexed question of truth: declare irrelevant what seems inconvenient if it serves your own interests. And these interests are pretty easy to identify. "Rubio ran for president in 2016," Chris Cillizza, CNN Editor-at-large, points out. "He would like to do so again maybe as soon as 2024. To do so successfully, Rubio will likely need to walk a very fine line between the Trump faction of the party and the bloc, currently (mostly) in hiding, who believe in a very different version of what the Republican Party can and should be." 25 Thus, there may be one more lesson to be learnt from the 2016 masterclass on truth-bending: Power is addictive. Abuse of power, whether in the White House or the Senate, even more so.

\section{Epilogue: Truth after Trump?}

There is no denying that 2016, that annus horribilis for democrats, has been a humbling experience for those who believed that common sense would prevail in the UK referendum, and that the United States would not really fall for an inexperienced, incompetent and self-obsessed business magnate who makes Scrooge McDuck look like an ascetic swami. Providing plenty of material for future generations of historians, 2016 also gives present-day commentators food for thought which is at times hard to digest. Liberal intellectuals and cosmopolitan progressives on both sides of the Atlantic have been taught a lesson by the

25 Cf. https://edition.cnn.com/2020/01/31/politics/marco-rubio-donald-trump-senateimpeachment-trial/index.html (July 17, 2020). 
masters of cunning and fraud, the habitual liars and narcissist populists: a true masterclass in post-truth fact meddling.

Since then, Dolus Trump has had a devastating impact in many fields, from climate change to transatlantic relations. His most dangerous political legacy, however, may well be the equally regressive and aggressive narrative of white grievance and American isolationism which brought him to power. Grounded in a paternalistic worldview, his bully instinct is fueled by a pathological narcissism. None of this is a secret, as in Hans Christian Andersen's tale The Emperor's New Clothes, in which frauds convince a vain emperor that they will weave him the most fashionable outfit. No-one dares end the ensuing farce, until a child points out the obvious truth: the emperor is naked. Like the townsfolk in the story, Republicans have decided that Number 45 is an ideal strongman, intolerable but effective.

My analysis of the Republican strategy during Trump's impeachment trial confirms what others have observed: the deep division of American society is reflected in the partisan impeachment trial. The Republican majority in the Senate succumbed to the temptation of power when it had the chance to admit that its emperor is naked. Dolus has carte blanche, as long as he keeps his party in power. This sets a dangerous precedent: If you run against the president, he may try to blackmail the head of state of a foreign government to produce incriminating evidence against you and members of your family. "Because the President is both the head of state and the Chief Executive of the Government," Bill Clinton wrote in his 2004 memoir, My Life, "he is in a sense the embodiment of people's idea of America, so reputation is important" (533). For four years, America has been represented by a "nasty man," as Joan Baez sang in 2017. What will happen next?

Understanding the emergence and climax of post-truth politics in the twenty-first century is a precondition for change; but given the deep divisions, inequalities, and partisanship which characterize American society today, a full reset seems rather unlikely. Truth cannot rely on Fate alone. Shared values and norms, social cohesion and solidarity, and trust in political systems are cornerstones of democracies as “imagined communities" in Benedict Anderson's sense (2016 [1983]). All of them have come under attack in the current age of uncertainty, frustration, and anger. Seen this way, Trump is not the cause, but a symptom of economic, political, and societal developments which Colin Crouch (2004) has called post-democracy. Nor is this a purely American problem, as the success of post-truth populism in Britain and Europe has shown. It is no coincidence that Brexit and Trump both happened in 2016. 
If democracy is to survive political climate change, we - the public sphere, the international community, science and academia, the people - must reclaim narrative authority over who we are, what we want to be. Acknowledging that truth is an elusive concept doesn't mean we can't - or shouldn't try to - establish a consensus about what we regard as facts and evidence. Epistemological relativism and populist discourses facilitate denial of science and the mistaken belief that all opinions are equal, willfully blurring the boundary between knowledge and ignorance. Democracies also need to review their aging systems of checks and balances to address the challenges of the digital age; in 2016, we saw how extensive election-meddling, established by the Mueller report, can change voting behavior. This is only the beginning - given the successful destabilization of the former superpower in a mere four years, it seems highly unlikely that America's competitors will stop exploring, expanding, and using their options.

The experiences of the Truth and Reconciliation Commission established in South Africa to overcome apartheid (segregation) offer some valuable suggestions. On the one hand, the distinction of four truth concepts - factual (forensic) truth, personal (narrative) truth, social (dialogue) truth, and healing (restorative) truth - identified by the Commission may help us to put an end to the proliferation of epistemological relativism which has become the hallmark of posttruth discourse. On the other hand, the function of legal proceedings, especially political trials, may benefit from engaging with African legal procedure which is based on an understanding that the primary goal is not the allocation of rights and wrongs between disputants but peacemaking, i. e. "reconciling the parties and reaching a decision that can be accepted by all” (Taylor 2007, 219). Partisan politics, tribalism, and institutional racism have created an American form of apartheid, both in the racist sense of segregation and the original meaning of separation, being apart. Political gridlock looms for America, even after a Biden victory, and gridlock increases frustration, as Brexit has shown. Some even fear that Dolus may refuse to leave and warn that it will take a landslide victory to get him out. ${ }^{26}$ One thing is certain, though: it will take a massive dose of healing truth to restore Truth.

26 Cf. https://www.theguardian.com/commentisfree/2020/jul/17/trump-biden-win-demo-cratlandslide (July 17, 2020). 


\section{Bibliography}

Ackermann, Spencer. "Senate Torture Report to Be Kept from Public for Twelve Years after Obama Decision.” The Guardian, December 12, 2016. https://www.theguardian.com/usnews/2016/dec/12/obama-senate-cia-torture-report-september-11-classified (July 15, 2020).

Aesop. Aesop's Fables. Trans. Laura Gibbs. Oxford/New York: Oxford University Press, 2008.

Anderson, Benedict. Imagined Communities: Reflections on the Origin and Spread of Nationalism. London et al.: Verso, 2006 [1983].

Baroni, Raphaël. "Tellability.” The Living Handbook of Narratology. Ed. Peter Hühn, Jan Christoph Meister, John Pier, Wolf Schmid. http://www.Ihn.uni-hamburg.de/article/tellability. Hamburg: Hamburg University, 2014 (July 17, 2020).

Breslow, Jason M. “Colin Powell: U.N. Speech 'Was a Great Intelligence Failure.” Frontline, 17 May 2016. https://www.pbs.org/wgbh/frontline/article/colin-powell-u-n-speech-was-agreat-intelligence-failure/ (July 15, 2020).

Bush, George W. “State of the Union Address.” Johnston's Archive, January 28, 2003. http://www.johnstonsarchive.net/policy/bushstun2003.html (July 15, 2020).

Butler, Judith. “Trump is Emancipating Unbridled Hatred." Zeit Online, October 28, 2016. https://www.zeit.de/kultur/2016-10/judith-butler-donald-trump-populism-interview (July 15, 2020).

Clinton, Bill. My Life. Volume I: The Early Years. New York: Vintage Books, 2004.

Crouch, Colin. Post-Democracy. Cambridge: Polity Press, 2004.

Griffin, Lisa Kern. “Narrative, Truth, and Trial.” Georgetown Law Journal (2013): 281-335.

Kessler, Glenn, Salvador Rizzo, and Meg Kelly (The Washington Post Fact Checker Staff). Donald Trump and His Assault on Truth: The President's Falsehoods, Misleading Claims and Flat-Out Lies. New York et al.: Scribner, 2020.

Leonhardt, David, Ian Prasad Philbrick, and Stuart A. Thompson. “Opinion: Trump's Lies vs. Obama's." New York Times, December 14, 2017.

https://www.nytimes.com/interactive/2017/12/14/opinion/sunday/trump-lies-obamawho-is-worse.html (July 15, 2020).

Luning, Ernest. “Impeachment: Garnder Says He Doesn’t Want to Hear from More Witnesses.” Colorado Politics, June 21, 2020. https://www.coloradopolitics.com/news/impeachmentgardner-says-he-doesnt-want-to-hear-from-more-witnesses/article_bb929014-42b1-11eab63d-27950ffe1e5f.html (July 15, 2020).

McIntyre, Lee. Post-Truth. Cambridge: Massachusetts Institute of Technology Press, 2018.

Mueller, Robert S. "Roger Stone Remains a Convicted Felon, and Rightly So." The Washington Post, July 11, 2020. https://www.washingtonpost.com/opinions/2020/07/11/muellerstone-oped/ (July 15, 2020).

Pinker, Stephen. The Stuff of Thought: Language as a Window into Human Nature. London: Penguin Books, 2007.

Ryan, Marie-Laure. Narrative as Virtual Reality 2: Revisiting Immersion and Interactivity in Literature and Electronic Media. $2^{\text {nd }}$ ed. Baltimore, MD: Johns Hopkins University Press, 2001.

Schuessler, Jennifer. “An Open Letter on Free Expression Draws a Counterblast.” New York Times, July 10, 2020. https://www.nytimes.com/2020/07/10/arts/open-letterdebate.html (July 17, 2020). 
Siegumfeldt, I. B., and François Hugonnier. "Interview with Paul Auster." LISA: Literature, History of Ideas, Images and Societies of the English-Speaking World 18.50 (2020). https://journals.openedition.org/lisa/11367 (July 17, 2020).

Taylor, David. “'The truth the whole truth nothing but the truth': Truth, Community and Narrative in African Procedural Law." The Comparative and International Law Journal of Southern Africa 40.2 (2007): 215-236.

Todorov, Tzvetan. “The Typology of Detective Fiction." Modern Criticism and Theory: A Reader. Ed. David Lodge, Nigel Wood. $3^{\text {rd }}$ ed. Harlow et al.: Pearson Longman, 2008 [1966]. 226232.

Trump, Mary. Too Much and Never Enough: How My Family Created the World's Most Dangerous Man. New York et al.: Simon \& Schuster, 2020. 